\title{
A KLÍMAÉRTÉKELÉS ERDÉSZETI VONATKOZÁSAI
}

\author{
Führer Ernő \\ NAIK Erdészeti Tudományos Intézet, Erdőmüvelési és Ökológiai Osztály - Soproni Egyetem, Erdőmérnöki Kar
}

\begin{abstract}
Kivonat
A klíma igen dinamikusan változó termőhelyi tényezővé vált, ezért szükséges az erdészeti klímaosztályozás átértékelése, az eddigieknél tudományosabb, öko-fiziológiai alapokra helyezése. A klíma egzakt értékelése céljából kidolgoztunk egy olyan mutatószámot (erdészeti szárazsági mutatószám), mely alapján most már egzakt meteorológiai adatokkal tudjuk az erdészeti gyakorlatban alkalmazott klímakategóriákat jellemezni, térbelileg lehatárolni, és változásukat nyomon követni. Az erdészeti szárazsági mutató segítségével pontosíthatjuk az erdészeti adattár egyes erdőrészleteinek klímabesorolását, ami önmagában is ágazatunk egyik legjelentösebb innovációs eredményének tekinthetö. Az adattári klímabesorolás felülvizsgálata azért is fontos, mert a klímakategóriáknak általános erdőgazdálkodási összefüggései is vannak, azaz hozzájuk ökológiai, erdőmüvelési (technológiai) és ökonómiai feltételek kapcsolódnak. Az ezek között fennáló összefüggések mélyreható ismerete lehetővé teszi az erdészeti termőhely-tipológia korszerüsitését. Erre támaszkodva pedig kifejleszthető egy olyan Erdészeti Döntéstámogató Rendszer, melynek gyakorlati alkalmazásával az erdőgazdálkodás bizonyos kompromiszszumok árán képes lesz a jövőbeni klímaváltozás kihívásainak megfelelni.
\end{abstract}

Kulcsszavak: erdészeti klímaosztályozás, erdészeti szárazsági mutató, erdészeti klímakategóriák.

\section{FORESTRY ASPECTS OF CLIMATE EVALUATION}

\begin{abstract}
In contrast to the other site factors, climate has shown a relative fast changes in the last decades. This emphasised the need of the rethink of the existing forest climate classification based on a more scientific, ecophysiological approach. For the more exact assessment of the climate, a new indicator (Forestry Aridity Index; FAl) has been developed that characterizes the forest climate categories with meteorological variables, thus the area of these categories and its observed and expected changes can be captured. FAl enables the more accurate climate categorization of the forest regions in the forest inventory, which is one of the most important innovation in the forestry sector. Revision of the climate classification of the inventory is important, since the categories have also general forest management contexts, i.e. ecological, management and economic conditions are associated with them. In-depth understanding of these relationships allows the renewal of forestry site typology. Based on this, it is possible to develop a Decision Support System for forestry that can be applied to adapt to climate change its impacts.
\end{abstract}

Keywords: climate classification in forestry, Forestry Aridity Index, forest climate categories. 


\section{KLÍMA ÉS AZ ERDŐ KAPCSOLATA}

Már csaknem 150 éve köztudott, hogy a klíma, mint fontos termöhelyi tényező, nagymértékben és sokoldalúan hat az erdőkre. Nemcsak az egyes fafajok elterjedését és ezen keresztül az erdők összetételét határozza meg, hanem az éghajlat jellege az erdők átlagos szervesanyag-produkcióját, sőt a faanyag müszaki felhasználhatóságát is befolyásolja. Természetesen a rövidebb, néhány évre vagy évszakokra kiterjedő időszakok meteorológiai viszonyai is hatással vannak az erdők évi növedékére, magtermésére, egészségi állapotának alakulására, az erdei fauna fejlődésére, a tűzveszély fokozódására vagy csökkenésére, a fakitermelés és anyagmozgatás mikéntjére és a felújitási munkákra. Ezért a szakszerü és tartamos erdőgazdálkodás, valamint az erdők területének növelése indokolja a klimatikus tényezőknek, elsősorban a hőmérsékleti és csapadékviszonyoknak, valamint e két tényező változásának és változékonyságának alaposabb ismeretét.

A környezeti tényezők és az erdőtársulások között sokoldalú kölcsönhatás érvényesül, hö-, víz- és tápanyagforgalmuk általában dinamikus egyensúlyban van, amiben nemcsak a klíma erdőre gyakorolt hatása, hanem az erdő klímaszabályozó szerepe is megnyilvánul (Bonan 2008). Az erdő lokális léptékben a csapadék eloszlását, a levegő és a talaj hőmérsékleti változásait, a légáramlást és a levegő nedvességét befolyásolva különleges adottságokat teremt. Alapvető fontosságú kérdés jelenleg, hogy amikor klímánk már az elmúlt 50 évben is nagymértékben változott (Lakatos \& Bihari 2011) és a jövőben az egyes elörejelzések alapján jelentősen változni fog (Bartholy et al. 2007, Gálos et al. 2015), akkor az erdei ökoszisztémák sajátos összetételük és szerkezetük révén miként tudnak e gyors folyamatokhoz alkalmazkodni és azokat müködésükön keresztül befolyásolni.

Ezért az erdőben lezajló öko-fiziológiai folyamatok erdészeti aspektusainak feltárása, melyben szerepet kap a fafajok elterjedésének, vitalitásának és szervesanyag-produkciójának (növedék) az eddigieknél alaposabb megismerése, a jövőbeli szakszerü és fenntartható erdőgazdálkodás megalapozását szolgálhatja.

\section{ERDÉSZETI KLIIMAOSZTÁLYOZÁS MAGYARORSZÁGON}

A klímát valamely hely, terület vagy kisebb-nagyobb földrajzi egység (táj, tájcsoport stb.) átlagos időjárásaként definiálhatjuk. Az átlagos szó jelzi, hogy az időjárás rendkívül változékony, ezért az időjárási elemekböl csak bizonyos mértékig lehet az éghajlatra következtetni. Az erdésznek azonban mindig az erdőgazdálkodás elvárásaira kell tekintettel lennie, amikor a klímát értékeli. Ennek megfelelően hazai vonatkozásban az alábbi, időben is egymásra épülő szempontok mentén fejlődött az erdészeti klímaértékelés. 


\section{Az erdő jelenlétének mérlegelése}

Klimatikus szempontból leggyakrabban a hőmérséklettel és a csapadékkal jellemzünk egy-egy területet, de emellett nagyon szoros a kapcsolat a relatív légnedvesség és az erdők megjelenése között is. A transzspiráció intenzitása, a termőhely vízgazdálkodása ugyanis összefügg a relatív páratartalommal, aminek nagysága sok egyéb tényező mellett leginkább a hőmérsékletnek és a transzspirációhoz szükséges vizet szolgáltató csapadéknak a függvénye. Már a múlt század elején Kaminszki (1924) térségünk erdősültségét a 13 órakor mért relatív páratartalom 79-68\%-áig terjedő évi középértékeivel, ill. a 13 órakor mért 64-50\%-áig terjedő júliusi középértékekkel hozta kapcsolatba, vagyis a természetes erdősültségü területeknek legalább ilyen relatív légnedvességüeknek kell lennie. Mivel hazánkban a 14 órai légnedvesség alacsonyabb a 13 órainál, ezért nálunk ezt az értéket vették számításba. Eszerint, a múlt századi megfigyelések alapján a kérdéses időpontban még az alföldi területek nagy része is elérte az 50\%-os relatív páratartalmat, azaz a csapadéktól függő vízellátottság lehetővé teszi a zárt erdőtakaró jelenlétét (Magyar 1960). Az Alföld középső részén, ahol a júliusi 14 órai relatív páratartalom $50 \%$ alatti, már csak az erdő- és a sztyep klíma átmenete, az erdőssztyep klíma figyelhető meg. A sokéves csapadék azonban e területeken is eléri az 500 és $550 \mathrm{~mm}$-t, ami még nem tekinthető a Köppen-féle szárazsági határ $(P=2(T+14))$ alapján sztyepterületnek (Köppen 1931). Ugyanis jelenleg az Alföldön a sokéves átlagcsapadék centiméterben kifejezett nagysága mindenhol nagyobb a 14-gyel növelt sokéves átlaghőmérséklet kétszeresénél. Az Alföld középső részén azonban az egyes évek több mint 30\%-ában már sztyepklíma fordul elő, azaz szárazság uralkodik. Viszont, amilyen arányban kileng az Alföld klímája a szárazság irányába, ugyanolyan arányú kilengés figyelhető meg az ellenkező irányba is. Szerencsére az éves csapadékeloszlás nem tekinthető kedvezőtlennek, hiszen a nyári hónapokban esik a legtöbb csapadék.

\section{A klímazonális fafajok elterjedésének figyelembevétele}

Az 1960-70-es években, Kaminszki eredményeire építve Magyarországra kidolgozott erdészeti klímaosztályozás is a légnedvesség alapján történt. Hazai megfigyelések alapján az erdők zonális elterjedése és a júliusi $65 \%$-os légnedvesség átlagvonala egybeesik (Járó 1962). Mivel a légnedvesség napi menetében az éjszakai órák, az évi menetében pedig a téli és tavaszi hónapok jelentős kiegyenlítést okoznak, ezért az átlagos adatok kevésbé jellemzik a fák számára döntő vízleadás mértékét. Így a zonális fafajok elterjedésének szétválasztására a júliusi 14 órai relatív páratartalom tűnt a legalkalmasabb mutatószámnak (Járó 1972). Ezt alátámasztja Stefanovits (1963) azon megállapítása is, miszerint „az 50\%-os légnedvességet jelentő vonal szinte tökéletes hasonmása annak, amit akkor kapunk, ha a csernozjom területeket határoljuk körül egy vonallal." Ez a talajtanban ismert megállapítás alátámasztja azt a feltételezést, miszerint erdőtalajok elsősorban zonális erdőtársulások alatt alakulhattak ki. 
A relatív légnedvesség havonkénti átlagai általában egy júliusi minimumot és egy decemberi maximumot mutatnak, ennek ellenére igen instabil meteorológiai elemnek mondható, mert mind térben, mind időben igen gyorsan változhat. Időbeli alakulását a termodinamikai (felmelegedés és lehülés) és a cirkulációs (légáramlatok páraszállitása) folyamatok jelentösen befolyásolják. Mindenesetre, ami a területi eloszlását illeti, megfigyelhető, hogy általában a legalacsonyabb páratartalmú területeink egybeesnek a legmelegebb tájainkkal, viszont a téli (december) legnagyobb párateltségü területeink nem a leghidegebbek. Minthogy az év legmelegebb hónapjában a legalacsonyabb a levegő relatív nedvessége, természetes, hogy ekkor a vegetációk, köztük a faállományok párologtatása igen intenzív. Amennyiben a talajban a transzspirációhoz szükséges vízmennyiség nem áll a fafajok rendelkezésére, úgy egy bizonyos mértéken felül ennek kedvezőtlen hatása a növedékkiesésen és vitalitás-csökkenésen keresztül is megnyilvánulhat.

Tekintettel arra, hogy területi és időbeli változatosságuk miatt a légnedvességi átlagok is, hasonlóan a többi meteorológiai paraméterhez, csak korlátozott mértékben használhatók, odavezetett, hogy egy adott terület klímájának megállapítása közvetett úton, ún. klímaérzékeny fafajokkal történjék. Magyarországon erre alkalmas fafaj a bükk, a gyertyán, a kocsánytalan tölgy és a cser. 62 meteorológiai állomás adatai és környezetében lévő erdőtársulás alapján azt a következtetést vonták le, hogy bükkös klíma ott van, ahol a júliusi 14 órai légnedvesség átlaga 60\%-nál magasabb, gyertyános-tölgyes a klíma, ahol 55\% és 60\% közötti, kocsánytalan tölgyes ill. cseres klíma 50-55\% légnedvesség mellett jellemző, míg ahol 50\% alatti ez az érték, az már fafajjal nem jellemezhető, ún. erdőssztyep klímájú (Járó 1972). Ezen értékeket további klímaállomások bevonásával a későbbiekben felülvizsgáltuk, és a fenti határokat 2\%-kal lejjebb húztuk meg (Führer \& Járó 2000). E klímaosztályozás még ma is szerves részét képezi az erdészeti termöhely-tipológiának.

\section{A fafajok éven belüli növekedését és vitalitását tekintetbe vevő értékelés}

A XXI. század legnagyobb kihívásai közé tartozik a klímaváltozás. Ennek számos következménye látható az erdőgazdálkodás vonatkozásában is, a korábbi céloktól eltérően általános kérdésként fogalmazódik meg a kutatás felé, hogy

- mik és milyenek az erdei ökoszisztémák reakciói a változatos és egyre inkább változó környezetre?

- erdőgazdálkodás révén hogyan teljesíthetjük az ökológiai és ökonómiai funkciók egyidejü érvényesítését?

- mi módon marad és lesz ágazatunk versenyképes?

A feltett kérdések megválaszolásához ezért az eddigiektől eltérően elengedhetetlen a klíma olyan értékelése, amely figyelembe veszi az erdő legfontosabb produktumának, a faanyagnak a képződésével összefüggő öko-fiziológiai folyamatokat, és bizonyos mértékig az erdei fák életképességét befolyásoló klimatikus körülményeket is. A fák és a faállományok 
növekedési feltételeinek minél alaposabb feltárása a klímaváltozás ökonómiai következményei (Führer et al. 2013) és az erdők klímavédelmi szerepe miatt is egyre inkább sürgető kutatási feladattá válik. Az erdészeti termőhely-tipológiában alkalmazott klímaértékelés továbbfejlesztése még azért is szükséges, mert

- a fafajok elterjedése a 200 évre visszatekintő szakszerủ erdőgazdálkodás miatt módosult,

- a relatív légnedvesség-mérések az erdészeti kiértékelésekhez megfelelő területi eloszlásban nem állnak rendelkezésünkre,

- az erdészeti klímakategóriák jellemzéséhez nincs elegendő egzakt meteorológiai adat, ami megalapozná a jövőre vonatkozó klíma-elörejelzéseket.

Ezért olyan klímaosztályozásra van szükség, amely támaszkodva a múlt eredményeire:

1. a fafajok elterjedése mellett figyelembe veszi

- azok növekedési szakaszainak (fö növekedési periódus: V-VIII. hó) időjárási viszonyait,

- a fafajok egészségi állapotát jelentősen befolyásoló időszakok (kritikus periódus: VII-VIII. hó) időjárási körülményeit,

2. továbbá olyan meteorológiai adatokra épít,

- melyeket az országban sok helyen, nagy pontossággal hosszú idő óta mérnek és nem matematikai modellek segítségével számítanak,

- területi és időbeli extrapolálásuk nagy biztonsággal megoldható,

- származtatott index képzésére alkalmazhatóak,

- és amelyek korszerü adatbázisokban a felhasználók számára rendelkezésre állnak.

\section{A növekedés és szervesanyag-képzés öko-fiziológiai folyamatainak megvilágítása}

A fák éves növekedésének vizsgálatakor meg kell különböztetni a tényleges növekedési periódust és az erdészeti gyakorlatban az időjárás jellemzésére sematikusan használatos vegetációs periódust (IV-X. hónapok). Vegetációs időszak alatt azt a periódust értjük, amelyben a potenciális növekedés megvalósulhat. A mérsékelt övi klímában általában a kései és a korai fagyok közötti időszakot értjük alatta (Linderholm 2006). A növekedési periódus pedig az az időszak, amiben a fák tényleges növekedése (hajtás- vagy vastagsági) bekövetkezik, vagy egyéb fiziológiai folyamatok, mint pl. a rügyszerkezet képződése megvalósul. Tekintettel arra, hogy Magyarország természetföldrajzi viszonyai jelentősen eltérnek Európa más országaitól, nagyobb hangsúlyt adunk a tudományos háttér megvilágításánál a magyarországi tanulmányok ismertetésének. Magyarországon több fafajon végzett törzsvastagsági növekedésmenet-megfigyelések igazolták, hogy a vastagsági szervesanyag-képzés több 
mint 80\%-a a május és augusztus közötti időszakban, a többi pedig e hónapokat megelözően és utána történik (Szőnyi 1962, Halupáné 1967, Járó \& Tátraaljainé 1985, Führer 1995, Manninger 2004, Führer et al. 2016). Ebben az ún. fő növekedési szakaszban a fák fotoszintézise intenzív, továbbá víz- és tápanyag-hasznosítása nagy. Természetesen a teljes növekedési periódus tényleges hossza, azaz kezdete és befejeződése közötti időszakasz az időjárási viszonyoktól függően évröl évre változhat. A vastagsági növekedés maximális mértéke Magyarország természetföldrajzi viszonyai mellett szinte valamennyi fafajnál júniusra tehető. A nettó fotoszintézis mértéke ebben a hónapban a legnagyobb, ami nagyban függ az időjárástól. A fák vastagsági növekedésének mértéke tehát a fotoszintézist közvetlenül befolyásoló tényezőktől, elsősorban az időjárástól függ (Lyr \& Hoffmann 1992). Különösen érzékenyen reagálnak az éven belüli növekedésükön keresztül a fák az olyan időjárási szélsőségekre, mint amilyen pl. az aszály vagy az asszimiláló felület rovar- és/vagy gombakárosítás miatti csökkenése. Magyarországon, mint állandósult éghajlati jellemvonás, gyakran fordul elő nyáron csapadékhiány és magas hömérséklet. E tényezők külön-külön is, de föleg ha együtt lépnek fel, jelentősen mérséklik a szervesanyag-képzés intenzitását, csökkentik annak nagyságát, továbbá befolyásolják a korai és kései pászták arányát is.

A hömérséklet különbözőképpen hat a növekedési folyamatokra. Magyarországi megfigyelések szerint is $5^{\circ} \mathrm{C}$ felett indul meg a legtöbb lombos fa átmérö-növekedése, de intenzívebb szervesanyag-képzés csak a $10^{\circ} \mathrm{C}$-os átlaghőmérsékletet meghaladó napok bekövetkezését követően figyelhető meg (Szőnyi 1962, Halupáné 1967). Az egyes fafajok szervesanyag-képzésének optimális hőmérsékleti tartománya más és más, pl. bükk esetében 13 és $23^{\circ} \mathrm{C}$, a molyhos tölgynél pedig $17-27^{\circ} \mathrm{C}$ közé esik (Pisek et al. 1969). Magyarországon májusban egyáltalán nem és júniusban is csak ritkán, bár az utóbbi években egyre gyakrabban lépi túl a nappali hőmérséklet ezen értékhatárt. Júliusban és augusztusban viszont már a havi átlaghőmérséklet is megközelíti a fotoszintézis optimális hömérséklet-tartományának felső határértékét. A nappali maximális értékek pedig egyre gyakrabban elérik azt a kritikus szintet $\left(35-40^{\circ} \mathrm{C}\right)$, amikor a fotoszintézis mértéke drasztikusan lecsökken. Ezért a júliust és augusztust élettani szempontból kritikus hónapoknak tekintjük. Magas hőmérséklet esetében továbbá igen nagy a légzés energiaszükséglete is (Larcher 2001). A kambium osztódását nagymértékben befolyásolja még a fitohormonok közül az auxin, amely felelös az évgyürün belüli korai, illetve kései pászták kialakulásáért (Hoffmann \& Lyr 1992). A kezdeti magasabb auxinszint a korai pászták képződésének, a későbbi alacsonyabb szint pedig a kései pászták kialakulásának kedvez. A növekedést a levegő hőmérséklete mellett befolyásolja még a talaj hömérséklete is (Körner 1999, Baldocchi et al. 2005). Több kutatás is bizonyította, hogy $4{ }^{\circ} \mathrm{C}$ alatti talajhőmérsékletnél nincsen gyökérképződés (Tranquillini 1979, Körner 1999). Baldocchi et al. (2005) úgy találták, hogy a lomblevelü erdőkben a növekedés (szervesanyag-képzés) csak akkor kezdődik, ha a talajhőmérséklet az átlagos éves léghőmérséklet fölé emelkedik. Ez utóbbi érték a magyarországi bükkösök előfordulási területére vonatkoztatva $8,8^{\circ} \mathrm{C}\left( \pm 0,9^{\circ} \mathrm{C}\right)$.

A változó hőmérsékleti viszonyok mellett a fák szervesanyag-képzését a vízellátottság befolyásolja leginkább, aminek forrása a magyarországi erdők 85 \%-ában a csapadék. A 
Kárpát-medencében a legmelegebb hőmérsékletünek számító Magyarországon a fák növekedését a gyakori vízhiány korlátozza. Az erdő éves vízforgalmával és a vele szorosan öszszefüggő szervesanyag-képzéssel kapcsolatosan számos tanulmány jelent meg Magyarországon (Járó 1989, Führer 1994, 1995, 2008, Führer \& Járó 2000, Führer 2017). A fák éves vastagsági növekedésének három (kezdeti, fő és befejező növekedési) szakasza különíthető el (1. ábra). Ezen szakaszok csapadékviszonyainak értékelésénél azonban mindig figyelembe kell venni, hogy az erdőben, időben és térben egyaránt sok tényező kölcsönhatása érvényesül egyszerre. $E$ tényezők fel is erősithetik, de ki is egyenlíthetik a szélsőséges csapadékviszonyok hatását. Az októbertől májusig terjedő időszakot vízforgalmi szempontból tárolási szakasznak, a növekedés szempontjából pedig nyugalmi (XI-III. hó) ill. kezdeti (IV. hó) növekedési szakasznak nevezzük, attól függően, hogy a vegetációs periódus mikor kezdődik. Ebben az időszakban a korona- és az avar-intercepcióval csökkentett csapadék nagy része a talajba szivárog, és azt fokozatosan feltölti. Fiziológiai vízfelhasználás vagy egyéb veszteség az elfolyáson, illetve a mélybeszivárgáson kívül csekély. A téli és tavaszi csapadékhiány hatása a növekedésre nehezen határozható meg, hiszen a transzspirációs folyamatok csak később indulnak el. Ha viszont az áprilisi csapadékhiány nagy, és ez magas hőmérséklettel is együtt jár, akkor ennek hatása már jobban érzékelhető a fák növekedésében, különösen csemete- vagy fiatalos korban. A május-augusztusi hónapok alatti szakaszt fö vízfelhasználási, ill. a fö növekedési szakasznak nevezzük. Ekkor a korona- és az avarintercepcióval csökkentett csapadék csak a talaj felső rétegeibe tud beszivárogni, és a tárolási időszakaszban feltöltődött vízzel együtt elsősorban a szervesanyag-képzésre, kisebb mennyiségben pedig egyéb fiziológiai folyamatokra fordítódik. Ebben a ciklusban realizálódik az erdő növedékének csaknem 80\%-a, ezért a szélsőséges időjárási viszonyok, elsősorban a csapadékhiány hatása is ekkor érzékelhető leginkább, elsősorban növedékkiesés, vagyis részleges aszálykár révén. Augusztust követő 2 hónap (szeptember-október) a befejező növekedési szakasz. Ekkor a korona- és az avar-intercepcióval csökkentett csapadék a talaj felső rétegeit tölti csak fel, pótolja az intenzív vízfelhasználás hiányát, és elsősorban a vastagsági növekedésen kívüli egyéb életfolyamatok (termésképzés stb.) vízigényét elégíti ki. A kevesebb csapadék csak kismértékü növedékkiesést eredményezhet. A befejező növekedési szakasz növedéke fajlagosan és abszolút értelemben is általában akkor nagyobb, ha a fő növekedési szakasz alatt a kedvezőtlen időjárási viszonyok miatt növedékkiesés jelentkezik. Ha a fö és befejező növekedési szakasz igen nagy csapadékhiánya kiugróan magas július-augusztusi hömérséklettel párosul, akkor nemcsak növedékveszteség következhet be, hanem a fák szervesanyag-képzése szinte teljesen leáll. E folyamat azért következik be, mert a fák a transzspirációjukkal saját hőháztartásukat tartják egyensúlyban. Drasztikus mértékủ szárazság esetében a fák fiziológiai legyengülése oly mértékủ lehet, hogy azok elpusztulhatnak és az ilyen állományokban nagymértékü törzsszámcsökkenés lesz megfigyelhető. Magyarországon általában az ún. határtermőhelyekre ültetett nemesnyárasokra és lucosokra jellemző ez az ún. teljes aszálykár.

Ezért az erdészeti termőhely-tipológiában alapvetően szükséges klímaértékeléshez egy olyan mutatószámot kell alkalmazni, amely figyelembe veszi a fák növekedése és a klíma 
közötti ok-okozati kapcsolatot befolyásoló periódusok időjárási körülményeit, és olyan meteorológiai jellemzőkre épít, amelyeket hosszú idő óta az országban sok helyen rögzítenek, és amelyek térbeli és időbeli kiterjesztése, azaz területi és időbeli extrapolálásuk nagy biztonsággal megoldható. Ilyen az egyszerüsített erdészeti szárazsági mutató (Forestry Aridity Index, röviden FAl) (Führer 2010), melynek képlete a következő:

$$
F A I=100 \cdot \frac{T_{\text {átlag }(\mathrm{VII}-\mathrm{VIII})}\left[{ }^{\circ} \mathrm{C}\right]}{\mathrm{P}_{\mathrm{V}+\mathrm{VI}+2 \cdot \mathrm{VII}+\mathrm{VIII}}[\mathrm{mm}]}
$$

ahol Tátlag(VII-VIII) a kritikus hónapok (július és augusztus) átlaghőmérséklete;

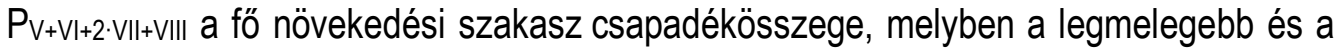
legalacsonyabb páratartalmú július csapadéka dupla súlyszámmal szerepel.

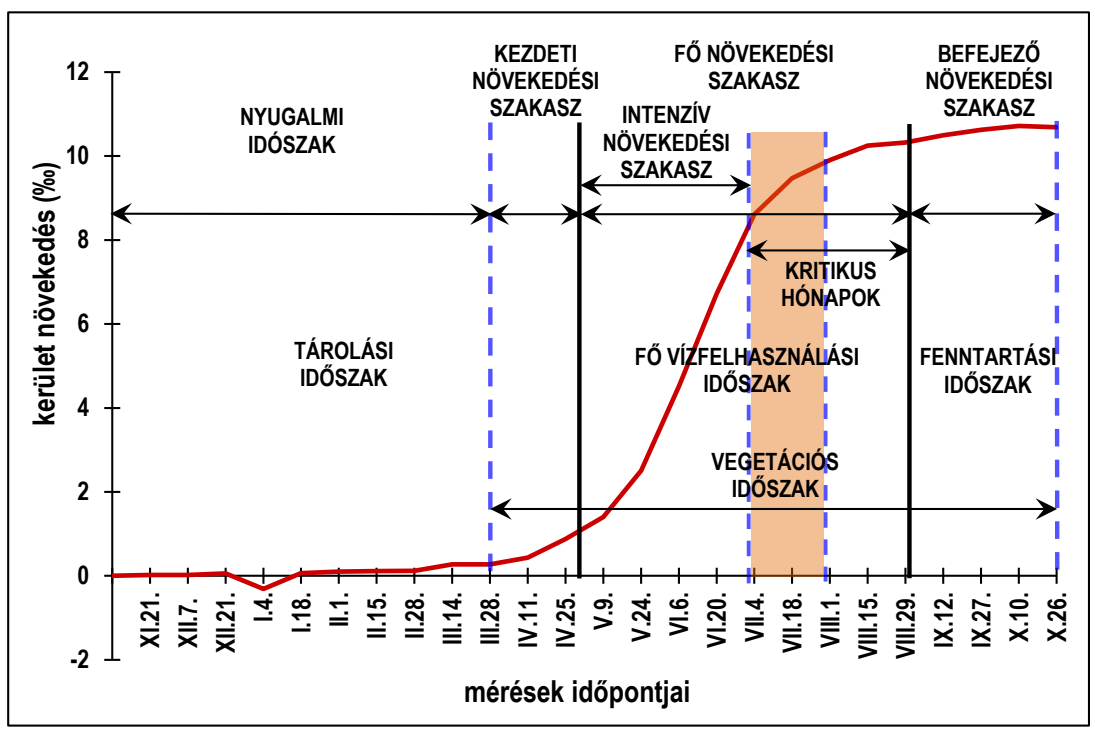

1. ábra: Növekedési görbe az öko-fiziológiai (vízfelhasználás) szempontból fontosabb periódusok bemutatásával.

Figure 1: Mean annual cycle of the basal area increment of the tree species in Hungary. The most relevant periods for the water use of the trees are indicated.

\section{ERDÉSZETI KLÍMAOSZTÁLYOK LEHATÁROLÁSA A FAI ALAPJÁN}

Hasonlóan, ahogy Járó (1972) a relatív légnedvességi adatokkal tette, 94 hazai meteorológiai állomás 1901-től 2000-ig tartó meteorológiai méréseinek adatbázisára, mindenhol a leghosszabb havi csapadék és hőmérsékleti idősorokra építve vizsgáltuk az egyszerüsített erdészeti szárazsági mutató használhatóságát. Az adatokból számított átlagos FAI mutatók 
és a térség zonális faállományai alapján nagy biztonsággal meghúzhatjuk az erdészeti klímahatárokat. E szerint a klíma

- Bükkös, ahol a FAl-érték 4,750 vagy az alatti.

- Gyertyános-tölgyes, ahol a FAl érték 4,751 és 6,000 közötti,

- Kocsánytalan tölgyes, ill. cseres, ahol a FAl érték 6,001 és 7,250 közötti, és

- Erdőssztyep, ahol a FAl érték nagyobb, mint 7,250.

E határértékek helyességét az erdészeti adatbázis több mint 11 ezer bükkös erdörészletére és mintegy 23 ezer kocsánytalan tölgyes, ill. cseres erdőrészletére extrapolált 1961 1990 közötti havi csapadék- és hőmérsékleti adatokból számított FAl-értékekkel is igazoltuk. Természetesen a klímaosztályok szétválasztására megadott határértékek nem olyan élesek, mint amit a számok mutatnak. A mezo- és a mikroklimatikus adottságok miatt átfedések vannak, ezért a FAl alapján történő klímaosztály-elhatárolás helyi szintű pontosítása indokolt. Ehhez figyelembe kell venni az adott időszak alatti időjárás évenkénti változékonyságát és a szélsőséges körülmények (kiugró csapadék- vagy hőmérsékleti viszonyok) előfordulásának gyakoriságát is. Vagyis az átlagos FAl értékeken belül lényeges, hogy egy, a klíma jellemzésére szükséges minimálisan 30 éves periódus alatt hányszor fordult elő pl. bükkös, gyertyános-tölgyes, cseres vagy erdőssztyep klímájú év, és milyen ezek eloszlása. Ennek megfelelően a több tízezer erdőrészletre extrapolált korrigált adatok alapján az egyes klímakategóriák határainál a klímabesorolása megerősítéséhez javasolt még ún. kiegészítő kritériumokat is figyelembe venni. Ha ezek nem teljesülnek, akkor, tekintettel a melegedő klímatendenciákra, mindig a melegebb és szárazabb klímakategória megállapítása a javasolt. Ennek megfelelően

- gyertyános-tölgyes és nem bükkös klímakategóriáról beszélünk, ha a megadott FAI értékhatár teljesülése mellett, a vizsgált időszakon belül a bükkös klímájú évek elöfordulása kisebb, mint 40\%, a bükkös és gyertyános-tölgyes klímájú évek együttes elöfordulása pedig kisebb, mint $70 \%$,

- kocsánytalan tölgyes ill. cseres és nem és gyertyános-tölgyes klímakategóriáról beszélünk, ha a megadott FAl értékhatár teljesülése mellett, a vizsgált időszakon belül a bükkös és gyertyános-tölgyes klímájú évek együttes előfordulása kisebb, mint $50 \%$,

- erdőssztyep és nem kocsánytalan tölgyes ill. cseres klímakategóriáról beszélünk, ha a megadott FAl értékhatár teljesülése mellett, a vizsgált időszakon belül az erdőssztyep klímájú évek előfordulása nagyobb, mint $60 \%$, az erdőssztyep és kocsánytalan tölgyes ill. cseres klímájú évek együttes előfordulása pedig nagyobb, mint $75 \%$.

\section{AZ ERDÉSZETI SZÁRAZSÁGI MUTATÓ GYAKORLATI ALKALMAZÁSA}

Az erdészeti szárazsági mutató egzakt meteorológiai adatok segítségével lehetővé teszi egy hely, egy táj, vagy esetleg még nagyobb földrajzi térség átlagos klímájának és annak 
változékonyságának jellemzését, méghozzá úgy, hogy abban kifejezésre jut a két legfontosabb, legegyszerübben mérhető időjárási tényezőnek, a hőmérsékletnek és a csapadéknak a faállományok fejlődésére gyakorolt hatása. A klímakategóriák lehatárolásával továbbá mód nyilik azok klíma- és időjárási viszonyainak jellemzésére is (Führer et al. 2011, 2017b).

A klíma és az erdő kapcsolatának alaposabb feltárása azonban a gyakorlat számára rendkívül fontos, mert az idáig csak feltételezésekre alapozott alkalmazási, ill. hasznosítási célok mellett új irányokat is kijelöl.

\section{Az erdészeti klímaosztályok területi megoszlása az országban}

Az erdészeti szárazsági mutató országos kiterjesztésű meghatározásához a földrajzi koordináta rendszerben, $1 / 6$ fokos rácsbontásban először meteorológiai adatbázist hoztunk létre (OTKA CK 80305/80335). Az adatbázis tartalmazza az elmúlt 50 évre (1961-2010) vonatkozóan a havi minimum, maximum és átlaghőmérséklet, a havi csapadék, valamint a relatív nedvesség adatait, melyek az OMSZ meteorológiai mérőállomásain mért adatok alapján a rácsközéppontok (4426 db) koordinátáihoz lettek interpolálva. Az adatbázisra alapozva vizsgáltuk az egyszerüsített erdészeti szárazsági mutató használhatóságát, lehatároltuk és meteorológiai szempontból jellemeztük az erdészeti klímaosztályokat (Führer 2017, Führer et al. 2017b). A lehatárolás elvi szempontjait figyelembe véve 1961-től 1990-ig terjedő, a klímaváltozás szempontjából ún. bázis időszak alatt az ország területének 5,5\%-a bükkös, 28,9\%-a gyertyános-tölgyes, 46,5\%-a kocsánytalan tölgyes ill. cseres és 19,1\%-a erdőssztyep erdészeti klímakategóriába tartozott (2. ábra). A rákövetkezö, 1981-től 2010-ig terjedő időszakkal történt összehasonlítás azt mutatja, hogy a FAI szerinti klímaosztályok területváltozása az elmúlt 50 év alatt egyértelmüen kedvezőtlen irányú. Amíg a bükkös klímakategória aránya 2,1\%-ra, a gyertyános-tölgyesé pedig 21,0\%-ra csökkent, addig a kocsánytalan tölgyes, ill. cseres klímaosztályé $51,8 \%$-ra, az erdőssztyep klímaosztály területe pedig $25,1 \%$-ra növekedett.

Az elemzésekből az elmúlt 50 év viszonylatában megállapitható, hogy az erdészeti szárazsági mutató változása, melyben a kritikus hónapok és a fő növekedési szakasz időjárási viszonyainak összhatása jut kifejezésre, az egyes országrészekben eltérő. Nagy általánosságban mondhatjuk, hogy 50 év alatt Dél-, Délnyugat- és Nyugat-Dunántúlon, valamint az Alföld déli és északkeleti részén növekvő trendü a változás és ennek mértéke több mint 1 FAl-érték, azaz csaknem egy klímakategóriát átfedő nagyságú. A Nagyalföld középső részein pedig éppen fordított a helyzet, az évenkénti FAl-értékek trendje csökken, azaz a klíma kedvezőbb irányba változik, de ennek mértéke alacsony. Ez azért van így, mert a hőmérséklet növekedése mellett a csapadék mennyisége is nőtt 1981-2010-ben az 1961-1990eshez képest. A többi országrészben viszont a felmelegedés és a kisebb mértékű csapadéknövekedés miatt inkább stagnálás figyelhető meg. 


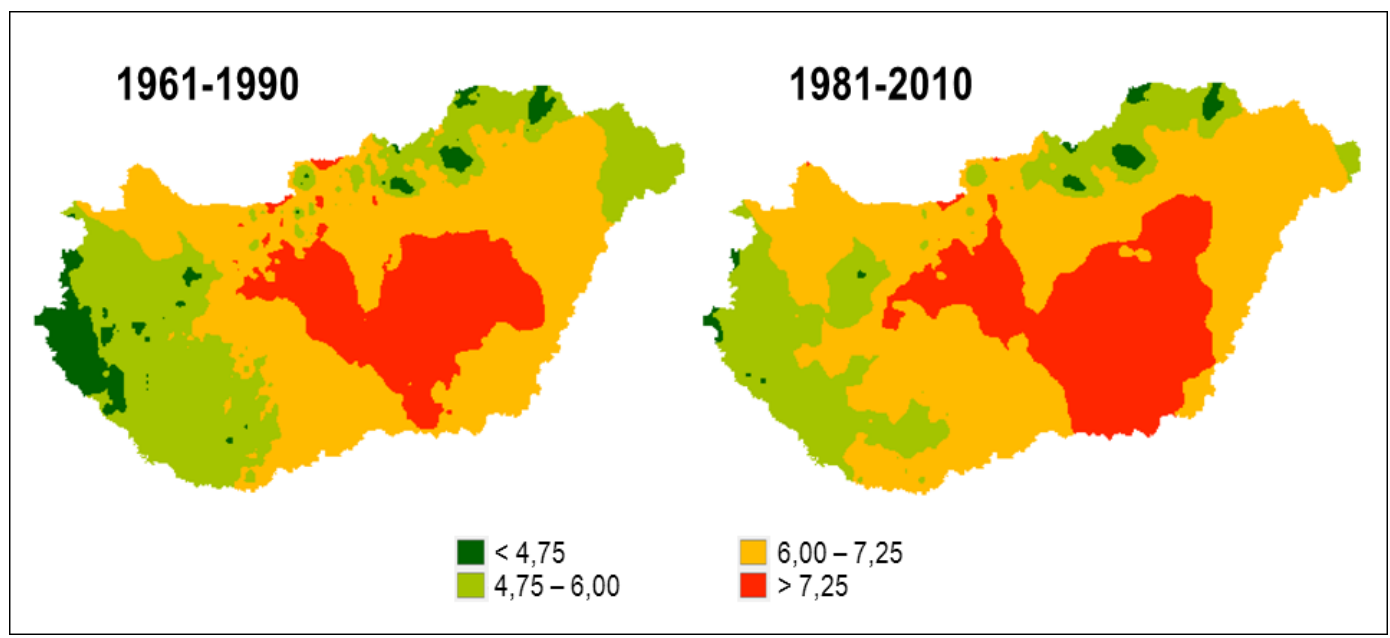

2. ábra: Erdészeti klímaosztályok előfordulása az1961-1990 és az 1981-2010 időszakok átlagos FAl-értékei alapján.

Figure 2: Macroclimatically suitable areas for the climate indicator tree species in the recent decades in Hungary based on the Forestry Aridity Index. The characteristic FAl threshold values are the following:

Beech climate category: FAI $\leq 4.75$, Hornbeam-oak climate category: $4.75<F A I \leq 6.0$,

Sessile oak - Turkey oak climate category: $6.0<F A l \leq 7.25$,

Forest steppe climate category: $7.25<F A l \leq 8.50$

\section{Adattári klímabesorolások pontosítása}

Az Erdőadattárban szereplő erdőrészletekre az egzakt meteorológiai paraméterek (FAl) alapján megállapított klímakategóriák jelentősen eltérhetnek az adattári, elsősorban a fafajok elterjedésével jellemezhető kategóriáktól (3. ábra). Például a Nagyalföld délkeleti részén fekvő Körös-Maros köze erdészeti tájban az adattár mindenhol, még a magyar-román határ közelében is erdősztyep klímabesorolást ad. Ezzel szemben a FAl alapú besorolás ennél kedvezőbb képet mutat, azaz a terület több mint 50\%-a kocsánytalan tölgyes, ill. cseres klímájú. A Mátra erdészeti tájban is hasonló a helyzet, vagyis a szárazabb és melegebb klímakategóriák aránya az Erdőadattárban magasabb, mint amit a FAl alapján számított értékek mutatnak, a változatos domborzati viszonyok és a hegyvidéki jelleg miatt azonban itt több klímakategória fordul elö. 


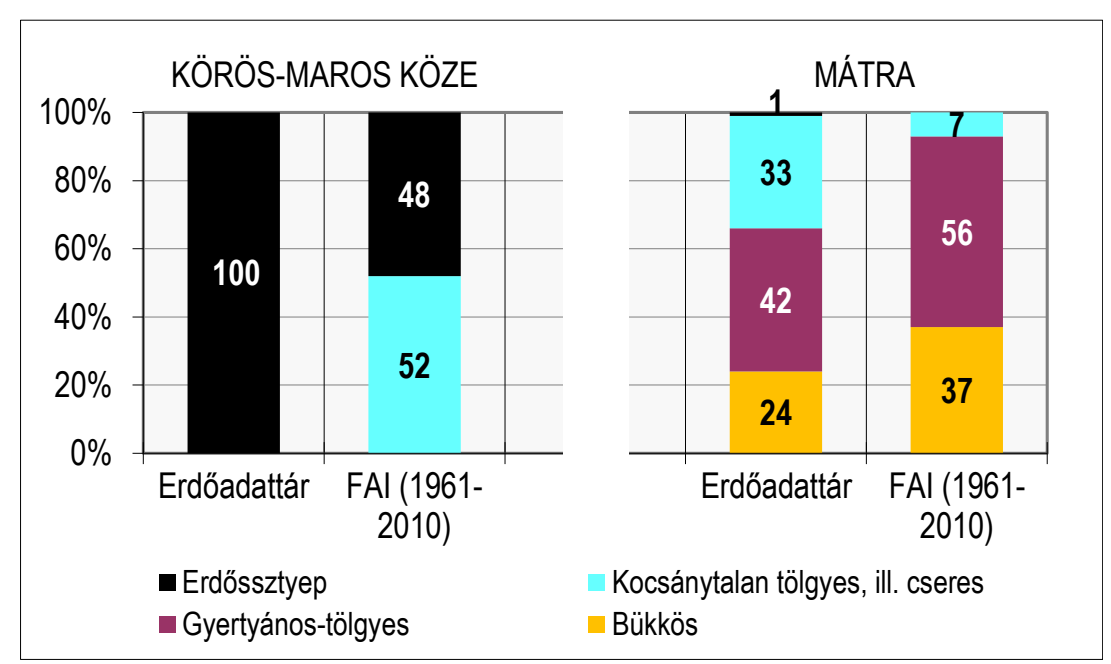

3. ábra: A Körös-Maros köze és a Mátra erdészeti tájak erdőinek klímakategóriák szerinti megoszlása az Erdőadattár és a FAl-értékek alapján.

Figure 3: Share of climate categories at forest areas in Körös-Maros köze and Mátra forest regions according to the National Forestry Database and the FAI.

Az adattári klímabesorolás felülvizsgálata azért is fontos, mert a klímakategóriáknak általános erdőgazdálkodási összefüggései is vannak, azaz hozzájuk ökológiai, erdőművelési (technológiai) és ökonómiai feltételek kapcsolódnak (Führer \& Járó 2000):

- A viszonylag hüvösebb és nedvesebb bükkös és gyertyános-tölgyes klímájú területek az erdőtenyészet számára optimális körülményeket jelentenek, rajuk természetes, részben természetszerü, nagy stabilitású ökoszisztémák (bükkösök, gyertyános-tölgyesek) élnek. A kocsánytalan tölgyes, ill. cseres klímájú területek már csak közepes adottságúak, az erdőssztyep klímában természetes, ill. természetszerü erdők már csak az ártereken és a felszínhez közeli talajvizü termöhelyeken alakulnak ki.

- Erdőművelés tekintetében, bükkös klímában teljes mértékben, a gyertyános-tölgyes klímában pedig nagyrészt természetes úton, magról, az eredeti populációkat megtartva lehet felújítani az őshonos fafajú és szerkezetű erdőket. A kocsánytalan tölgyes, ill. cseres klímában tenyésző erdők felújitása már csak kisebb részben történik természetes úton, nagyobb részben mesterséges úton, csemetével. Az erdőssztyep klímájú termőhelyek erdei mesterséges felújitású kultúrerdők, melyek fenntartása szakszerü beavatkozást igényel.

- A különböző klímakategóriák erdőinek ökonómiai értéke is eltérő. A bükkös és gyertyános-tölgyes klímájú erdök fahozama (növedéke) nagy, ökonómiai értéke magas. A kocsánytalan tölgyes, ill. cseres klímában tenyésző erdők fahozama általában közepes, a termesztési költségek magasabbak, ökonómiai értékük közepes, vagy gyenge. Az erdőssztyep klímájú erdők termesztési költségigénye magas, a fahozam 
a termőhelytöl függően igen változó, az ökonómiai érték pedig a fahozamtól függően gyakran gyenge.

Ezért mindenképpen javasoljuk az erdészeti igazgatás felé, hogy az egyes erdőrészletek jelenlegi és távlati klímabesorolásának az eddiginél biztosabb meghatározása érdekében az erdészeti adattárban nyilvántartott, az erdőgazdálkodás szempontjából fontos paraméterek közé vegye be az erdészeti szárazsági mutatót is. Az új erdészeti klimaértékelés ily módon történő továbbfejlesztése és gyakorlati bevezetése az erdészeti ágazat (kutatás, igazgatás és gyakorlat) szükségszerü és egyik legfontosabb innovatív eredménye.

\section{Az új klímaértékelés további felhasználási lehetőségei}

A FAl segítségével történő erdészeti klímaértékelés a már bemutatott gyakorlati felhasználásokon kívül több területen hozott új kutatási eredményt, melyek jórészt e tematikus kötetben ismertetésre kerülnek. Ezek közül három kiemelendő:

- egyrészt a globális klímaváltozás hatása miatt az erdészeti klímakategóriák területében várható módosulások rövid és hosszú távú elöre jelzése (Führer et al. 2011, 2017a, Gálos \& Führer 2018),

- másrészt az új klímaértékelés beépítése a Magyarországon müködő erdészeti termőhely-tipológia rendszerébe és így annak Erdészeti Döntéstámogató Rendszerré (EDTR) történő továbbfejlesztése (Mátyás 2017, Mátyás et al. 2018),

- végül pedig a klímaváltozáshoz alkalmazkodó szaporitóanyag-gazdálkodás megalapozása (Borovics 2018).

\section{ÖSSZEFOGLALÁS}

A tartamos erdőgazdálkodás eredményessége elsősorban a termőhely termőképességének optimális hasznosításán múlik. Mivel a klíma igen dinamikusan változó termőhelyi tényezővé vált, ezért szükséges az erdészeti klímaosztályozás átértékelése, az eddigieknél tudományosabb, öko-fiziológiai alapokra helyezése. Az erdőgazdálkodás csak így lesz képes a klímaváltozás következményeire megfelelő válaszokat adni.

A klíma egzakt értékelése céljából kidolgoztunk egy olyan mutatószámot (FAI), mely nem csak a klímazonális fafajok elterjedésének klímaviszonyait, hanem a növekedésüket meghatározó időszakok időjárási körülményeit is számításba veszi. A mutatószám alapján most már egzakt meteorológiai adatokkal tudjuk az erdészeti klímakategóriákat jellemezni és térbelileg is lehatárolni, továbbá a változást nyomon követni. Ennek megfelelően az 1961-1990es időszakban az ország területének 5,5\%-a bükkös, 28,9\%-a gyertyános-tölgyes, 46,5\%-a 
kocsánytalan tölgyes ill. cseres és 19,1\%-a erdőssztyep erdészeti klímakategóriába tartozott. A rákövetkező, 1981-től 2010-ig terjedő időszak alatt egyértelműen kedvezőtlen irányú a változás. Amíg a bükkös klímakategória aránya 2,1\%-ra, a gyertyános-tölgyesé pedig 21,0\%-ra csökkent, addig a kocsánytalan tölgyes, ill. cseres klímaosztályé 51,8\%-ra, az erdőssztyep klímaosztály területe pedig 25,1\%-ra növekedett.

A kimunkált erdészeti szárazsági mutató segítségével pontosíthatjuk az erdészeti adattár egyes erdőrészleteink klímabesorolását. Ez önmagában is ágazatunk egyik legjelentősebb innovációs eredményének tekinthető. Ugyanis a klímakategóriáknak nemcsak ökológiai, hanem erdőmüvelési és ökonómiai vonatkozásai is vannak. Csak az ezek között fennálló öszszefüggések mélyreható ismerete teszi lehetővé az erdészeti termőhely-tipológia korszerüsítését. Erre támaszkodva pedig kifejleszthető egy olyan Erdészeti Döntéstámogató Rendszer, melynek gyakorlati alkalmazásával az erdőgazdálkodás bizonyos kompromisszumok árán képes lesz a jövőbeni klímaváltozás kihívásainak megfelelni.

\section{KÖSZÖNETNYILVÁNÍTÁS}

A téma az Agrárklíma 2 projekt (VKSZ_12-1-2013-0034) keretében valósult meg. A korábbi megalapozó eredmények az OTKA CK 80305-80335 számú projektek keretében születtek.

\section{FELHASZNÁLT IRODALOM}

Baldocchi D.D., Black T.A., Curtis P.S., Falge E., Fuentes J.D., Granier A. et al. 2005: Predicting the onset of net carbon uptake by deciduous forests with soil temperature and climate data: a synthesis of FLUXNET data. International Journal of Biometeorology 49(6): 377-387. DOI: 10.1007/s00484-005-0256-4

Bartholy J., Pongrácz R. \& Gelybó Gy. 2007: Regional climate change expected in Hungary for 2071-2100. Applied Ecology and Environmental Research 5(1): 1-17. DOI: 10.15666/aeer/0501_001017

Bonan G.B. 2008. Forests and climate change: forcings, feedbacks, and the climate benefits of forests. Science 320: 1444-1449. DOI: 10.1126/science.1155121

Borovics A. 2018: A jövő már elkezdődött. Erdészeti Lapok 153(1): 2-5.

Führer E. 1994: Csapadékmérések bükkös-, kocsánytalantölgyes és lucfenyves ökoszisztémában. Erdészeti Kutatások 84: 11-35.

Führer E. 1995: Az időjárás változásának hatása az erdő fatermőképességére és egészségi állapotára. Erdészeti Lapok 130(6): 176-178.

Führer E. 2008: Erdőgazdaság. In: Harnos Zs., Gaál M. \& Hufnagel L. (eds): Klímaváltozásról mindenkinek. Budapesti Corvinus Egyetem, Kertészettudományi Kar, Matematikai és Informatikai Tanszék, Budapest, 90-102.

Führer E. 2010: A fák növekedése és a klíma. „KLÍMA-21” Füzetek 61: 98-107. 
Führer E. 2017: Az erdészeti klímaosztályok új lehatárolása öko-fiziológiai alapon. Erdészeti Lapok 152(6): 173-174.

Führer E. \& Járó Z. 2000: Az aszály és a belvíz érvényesülése a Nagyalföld erdőművelésében. Erdészeti Tudományos Intézet Kiadványai 12. Erdészeti Tudományos Intézet, Budapest.

Führer E., Horváth L., Jagodics A, Machon A. \& Szabados I. 2011: Application of a new aridity index in Hungarian forestry practice. Időjárás 115(3): 205-216.

Führer E., Jagodics A., Juhász l., Marosi Gy. \& Horváth L. 2013: Ecological and economical impacts of climate change on Hungarian forestry practice. Időjárás 117(2): 159-174.

Führer E., Edelényi M., Horváth L., Jagodics A., Jereb L., Kern Z. et al. 2016: Effect of weather conditions on annual and intra-annual basal area increments of a beech stand in the Sopron Mountains in Hungary. Időjárás 120(2): 127-161.

Führer E., Gálos B., Rasztovits E., Jagodics A. \& Mátyás Cs. 2017a: Erdészeti klímaosztályok területének várható változása. Erdészeti Lapok 152(6): 174-177.

Führer E., Horváth L., Móring A., Pödör Z. \& Jagodics A. 2017b: Az erdészeti szárazsági mutató (FAl) segítségével lehatárolt erdészeti klímaosztályok/klímakategóriák jellemzése. Erdészeti Lapok 152(9): 270-272.

Gálos B., Führer E., Czimber K., Gulyás K., Bidló A., Hänsler A. et al. 2015: Climatic threats determining future adaptive forest management - a case study of Zala County. Időjárás 119(4): 425-441.

Gálos B. \& Führer E. 2018: A klíma erdészeti célú előrevetítése. Erdészettudományi Közlemények 8(1): 43 55. DOI: 10.17164/EK.2018.003

Halupa L.-né 1967: Adatok a sziki tölgyesek növekedési menetének vizsgálatából. Erdészeti Kutatások 63: 95-108.

Hoffmann G. \& Lyr H. 1992: Phytohormone und synthetische Wachstumsregulatoren. In: Lyr H., Fiedler H.J. \& Tranquillini W. (eds): Physiologie und Ökologie der Gehölze. Gustav Fischer Verlag Jena/Stuttgart, 345369.

Járó Z. 1962: Termőhelyi tényezők ismertetése. In: Majer A. (ed): Erdő- és termőhelytipológiai útmutató. Országos Erdészeti Főigazgatóság. Budapest, 11-68.

Járó Z. 1972: A termőhely fogalma. In: Danszky I. (ed): Erdőművelés I. Mezőgazdasági Kiadó, Budapest, 4787.

Járó Z. 1989: Az erdő vízforgalma. Az Erdő 38: 352-355.

Járó Z. \& Tátraaljai E.-né 1985: A fák éves növekedése. Erdészeti Kutatások 76-77: 221-234.

Kaminszki A. 1924: Kelet-Európa klímatartományai, összehasonlítva az erdők elterjedésével. Petrograd (orosz nyelven).

Köppen W. 1931: Grundriss der Klimakunde. Walter de Guyter \& Co, Berlin/Leipzig.

Körner Ch. 1999: Alpine plant life. Springer, Heidelberg. DOl: 10.1007/978-3-642-18970-8

Lakatos M. \& Bihari Z. 2011: A közelmúlt megfigyelt hőmérsékleti és csapadéktendenciái. In: Bartholy J., Bozó L. \& Haszpra L. (eds): Klímaváltozás - 2011, Klímaszcenáriók a Kárpát-medence térségére. MTA-ELTE Meteorológia Tanszék, Budapest, 146-169.

Larcher W. 2001: Ökophysiologie der Pflanzen. 6. Auflage. UTB, Verlag Eugen Ulmer, Suttgart.

Linderholm H.W. 2006: Growing season changes in the last century. Agricultural and Forest Meteorology 137(1-2): 1-14. DOI: 10.1016/j.agrformet.2006.03.006

Lyr H. \& Hoffmann G. 1992: Wachstum - Einflussfaktoren. In: Lyr H., Fiedler H.J. \& Tranquillini W. (eds): Physiologie und Ökologie der Gehölze. Gustav Fischer Verlag, Jena/Stuttgart, 397-437.

Magyar P. 1960: Alföldfásítás. I. kötet: Általános és leíró rész. Akadémiai Kiadó, Budapest.

Manninger M. 2004: Erdei fák éves és korszaki növekedésmenete és kapcsolódása egyes ökológiai tényezőkhöz. In: Mátyás Cs. \& Vig P. (eds): Erdő és klíma IV. Nyugat-Magyarországi Egyetem, Sopron, 151-162.

Mátyás Cs. 2017: Az eDTR alapvető célkitüzései és működése. Erdészeti Lapok 152(10): 306-307.

Mátyás Cs., Berki I., Bidló A., Csóka Gy., Czimber K., Führer E. et al. 2018: Sustainability of forest cover under climate change on the temperate-continental xeric limits. Forests (megjelenés alatt) 
Pisek A., Larcher W., Moser W. \& Pack I. 1969: Kardinale Temperaturbereiche der Photosynthese und Grenztemperaturen des Lebens der Blätter verschiedener Spermatophyten. III. Temperaturabhangigkeit und optimaler Temperaturbereich der Netto-Photosynthese. Flora B 158: 608-630. DOI: 10.1016/S03671801(17)30246-6

Stefanovits P. 1963: Magyarország talajai. Akadémiai Kiadó, Budapest.

Szőnyi L. 1962: Adatok néhány fafaj vastagsági növekedéséhez. Az Erdő 11: 289-300.

Tranquillini W. 1979: Physiological ecology of the alpine timberline. Ecological Studies 31. Springer, Heidelberg/New York. DOI: 10.1007/978-3-642-67107-4

Érkezett: 2018. május 4.

Közlésre elfogadva: 2018. május 28. 